\title{
Soy Culture in Minimum Tillage and the Influence on Soil Attributes, ARDS Turda, 2005-2014
}

\author{
Felicia CHEȚAN ${ }^{1,2}$, Cornel CHEȚAN ${ }^{1,2}$, Teodor RUSU ${ }^{2 *}$, Alina ȘIMON ${ }^{1,2}$ \\ ${ }^{1}$ Agricultural Research and Development Station, Turda, 27 Agriculturii Street,401100, \\ Cluj County, Romania, Email: felice_fely@yahoo.com \\ ${ }^{2}$ University of Agricultural Sciences and Veterinary Medicine Cluj-Napoca, 3-5, \\ Manastur Street, 400372, Romania, \\ * corresponding author: rusuteodor23@yahoo.com
}

Bulletin UASVM series Agriculture 73(2)/2016

Print ISSN 1843-5246; Electronic ISSN 1843-5386

DOI 10.15835/buasvmcn-agr: 12408

\begin{abstract}
The system of agriculture conservative comes must halt this process of degradation and soil protection with carpets plant debris and intervention minimal on the ground shall be avoided the process of compaction erosion by increasing fertility. Excessive processing of agricultural land with mechanical equipment and primarily the work of basic-till that mobilizes soil in depth damage to a greater extent pests and diseases in the soil but it also has negative effect by losses mineralization weaker plant debris, breaking continuity capillarity and if an angry crowd on side slopes should be done after the line of the greatest slope will promote erosion.

By applying minimum tillage system soil at ARDS Turda, is intended primarily to combat soil erosion, keeping the water in the soil, increasing fertility, protection of the environment.
\end{abstract}

Keywords: Minimum Tillage, fertility, Soybean, soil compaction, climate conditions.

\section{INTRODUCTION}

By removing land vegetation are exposed to a prolonged rainfall and wind erosion favors. Strong erosion occurs on slopes. Water from precipitation (rain) falling on bare ground vegetation, slope, directly strikes the surface layer of soil and destroys it, some of the units are shot and bruised soil surface. Some water seeps into the ground, a small part evaporates, but mostly drains downstream, surface water leaks (Berca, 2006). Deep plowing lead to lower humus content, which is based on soil fertility of soil by enhancing oxidation processes of organic matter found after 15 years of experimentation (Stefanic et al., 1976,1997).

The literature shows that reducing tillage and increasing organic matter (remaining on the soil surface or in soil) helps restore soil structure (Carter, 1994).

Penetration resistance (Rp) is one of the main indicators characterizing (mechanical) the status of soil formation. This determination, measurement of soil compaction, are of special importance for the study of plant root system development and can soil penetration values below 300 PSI (2000 $\mathrm{kPa}$ ) does not adversely affect root penetration the ground and at higher values of 400-500 PSI $(2700-3400 \mathrm{kPa})$ in roots penetrate the soil is almost zero (Rusu et al., 2012).

From the literature study observed that new tillage systems depend on local pedo-climatic conditions, so choosing the system at least to take account of technological attribute soil: humidity, the exhibition ground, macro and microclimate, content in humus etc.

\section{MATERIALS AND METHODS}

Experiment realised at S.C.D.A. Turda, includes two ways of tillage, conventional (classical system) with autumn plowing, soil preparation, fertilization and sowing in parallel to the conservative („minimum tillage”) work 
with cisel - sowing + fertilizing, in a 3 years crop rotation: maize (Zea mays L.) - soybean (Glycine hispida L.Merr.) - autumn wheat (Triticum aestivum L.), with experimental variants that include technological measures that contribute to plant vegetation control in the experiment, namely: fertilization and treatments. Technology were comparatively studied in two agricultural systems (for a period of 10 years) will be able to monitor such comparative evolution under the work influence of the soil attribute, the influence of climatic factors, soil moisture estimation (accumulation and soil water storage) and wheat productions realised.

The experiments were performed on a vertic faeoziom soil type, $\mathrm{pH}$ ranging from 6.30 to 7.00 between hard; humus from 2.21 to $2.94 \%$; 0.162 to $0.124 \%$ total nitrogen; 0.9 to 5 ppm phosphorus; 126-140 ppm potassium. These values are determined on depth soil $0-40 \mathrm{~cm}$.

The experience is the type trifactorial, into three repetitions, organized by the method of subdivided parcels. The area of experimental plots is $48 \mathrm{~m} 2(4 \mathrm{ml} \mathrm{x} 12 \mathrm{~m} \mathrm{~L})$.

Experimental factors:

${ }^{*} \mathbf{A}$ - soil tillage system with 2 graduation: $A_{1}$ conventional tillage system; $A_{2}$ minimum tillage system.
${ }^{*} \mathbf{B}$ - Fertilizer with 2 graduation: $\mathrm{B}_{1}$ - the basic fertilization with $\mathrm{N}_{40} \mathrm{P}_{40} ; \mathrm{B}_{2}$ - the basic fertilization with $\mathrm{N}_{40} \mathrm{P}_{40}+\mathrm{N}_{30}$ by vegetation;

${ }^{*} \mathbf{C}$ - Years with 10 graduation: $\mathrm{C}_{1}-2005, \mathrm{C}_{2}-$ 2006, $C_{3}-2007, C_{4}-2008, C_{5}-2009, C_{6}-2010 ; C_{7}-$ 2011; $\mathrm{C}_{8}-2012 ; \mathrm{C}_{9}-2013 ; \mathrm{C}_{10}-2014$.

The biological material was represented by the Onix-of soybean. Sowing was done with the drill Gaspardo-Direct 400, which when sowing and fertilizing performed at $18 \mathrm{~cm}$ row spacing, seed depth of $5 \mathrm{~cm}$ incorporated amount of seed per hectare $110 \mathrm{~kg}$.

Tillage by plowing and with chisel was performed at $30 \mathrm{~cm}$ depth. Soil sampling (on depth $0-20 ; 20-40 \mathrm{~cm}$ ) was performed using probe type drill immediately after harvesting crop and send for physicochemical analyzed (OSPA Cluj) to determine fertility indices soil.

The method used to determine the $\mathrm{pH}$ was potentiometric method, for humus Walkley-Black method was used, nitrogen was determined by the Kjeldahl method for the colorimetric method was used phosphorus and flam photometric method was determined bet on soil potassium content. The most the root system it is on the first 30-40 $\mathrm{cm}$ soil, compaction determination was performed on the same depth, register concomitantly temperature and soil moisture existing at that

Tab. 1. The thermal regime ARDS Turda, 2005-2014

\begin{tabular}{|c|c|c|c|c|c|c|c|c|c|c|c|c|c|}
\hline \multirow{2}{*}{ Year } & \multicolumn{12}{|c|}{ Monthly average temperature $\left({ }^{\circ} \mathrm{C}\right)$} & \multirow{2}{*}{$\begin{array}{l}\text { Mean } \\
\text { anual }\end{array}$} \\
\hline & Jan & Feb & Mar & Apr & May & Jun & Jul & Aug & Sep & Oct & Nov & Dec & \\
\hline 2005 & -2.1 & -4.2 & 1.5 & 9.8 & 15.7 & 17.2 & 19.7 & 19.0 & 16.1 & 10.1 & 3.5 & -0.9 & 8.8 \\
\hline 2006 & -5.1 & -2.4 & 3.4 & 10.8 & 14.3 & 17.6 & 21.2 & 18.5 & 15.8 & 10.5 & 3.5 & -0.1 & 9.0 \\
\hline 2007 & 2.4 & 2.5 & 7.3 & 10.8 & 17.0 & 20.3 & 22.0 & 20.1 & 13.7 & 9.3 & 1.9 & -3.2 & 10.3 \\
\hline 2008 & -2.8 & 3.8 & 5.4 & 10.5 & 15.0 & 19.4 & 19.5 & 21.0 & 14.0 & 10.7 & 4.1 & 1.1 & 10.1 \\
\hline 2009 & -2.3 & -0.5 & 3.7 & 13.2 & 16.2 & 18.7 & 21.0 & 20.7 & 17.4 & 10.0 & 5.2 & 0.1 & 10.3 \\
\hline 2010 & -3.1 & 1.0 & 4.3 & 10.5 & 15.4 & 18.9 & 20.7 & 21.0 & 14.2 & 7.4 & 7.6 & -1.6 & 9.7 \\
\hline 2011 & -3.8 & -3.2 & 5.3 & 10.7 & 15.6 & 19.2 & 20.1 & 20.8 & 18.2 & 8.8 & 0.7 & 0.8 & 9.4 \\
\hline 2012 & -2.3 & -6.1 & 4.7 & 11.8 & 16.2 & 21.0 & 24.0 & 22.3 & 19.1 & 11.4 & 5.2 & -2.6 & 10.4 \\
\hline 2013 & -2.4 & 2.0 & 3.5 & 12.3 & 16.8 & 19.4 & 20.9 & 22.1 & 13.8 & 11.2 & 7.1 & -1.7 & 10.4 \\
\hline 2014 & 0.5 & 3.8 & 8.8 & 11.4 & 15.1 & 18.5 & 20.4 & 19.9 & 16.6 & 10.8 & 5.7 & 1,3 & 11,1 \\
\hline $\begin{array}{l}\text { Mean } \\
10 \text { years }\end{array}$ & -2.1 & -0.4 & 5.2 & 12.2 & 17.3 & 20.8 & 23.0 & 22.5 & 17.4 & 11.0 & 4.8 & -0.8 & 9.8 \\
\hline $\begin{array}{l}\text { Mean } \\
57 \text { year }\end{array}$ & -3.5 & -0.9 & 4.1 & 9.9 & 14.8 & 17.8 & 19.7 & 19.3 & 15.0 & 9.6 & 3.8 & -1.5 & 9.0 \\
\hline
\end{tabular}


time (August 2010, considered a normal year in terms of climate). The penetration resistance was determined with digital penetrometer FieldScout SC900.

To control weeds, pests and diseases (at the right time the most powerful attack), were performed complex treatments which include herbicides and insect-fungicide with low environmental impact.

The results were statstically analysed by ANOVA test (PoliFact)

Weather conditions subject experimental years (Meteorological Station Turda, longitude: $23^{\circ} 47$ " latitude $46^{\circ} 35^{\prime}$; altitude $427 \mathrm{~m}$ ) are shown in table 1 and table 2

From Tab. 1, it is noted that all 10 years taken in study, monthly values of temperature higher than multiannual average. The total period of 10 years studied 5 years had values above $10.0^{\circ} \mathrm{C}$ and values 10 years had an increase of $+0.8^{\circ} \mathrm{C}$. Year 2014 was the warmest year in the 57 years studied.

From Tab. 2, it can be seen that rainfall has increased over the last 57 years the wets years were 2005 and 2010. The average value of 598.2 $\mathrm{mm}$, the past 10 years, maintains in the area with average hydric aggression. Specific 10 years taking in study was uneven distribution of rainfall in months of the year. Were register dry periods, with prolonged soil droughts (example August 2011 in available until August 2012), followed by torrential rain that although they had large amounts of water, often failed to restore reserves dominating this drought for the entire period of time. Year 2014 was excessively rainy, second only to 2005 in the 57 years studied.

Tab. 2. The rainfall regime ARDS Turda, 2005-2014

\begin{tabular}{|c|c|c|c|c|c|c|c|c|c|c|c|c|c|}
\hline \multirow{2}{*}{ Year } & \multicolumn{12}{|c|}{ Precipitation - monthly amount $(\mathrm{mm})$} & \multirow{2}{*}{$\begin{array}{l}\text { Annual } \\
\text { amount }\end{array}$} \\
\hline & Jan & Feb & Mar & Apr & May & Jun & Jul & Aug & Sep & Oct & Nov & Dec & \\
\hline 2005 & 24.3 & 27.7 & 33.3 & 81.5 & 54.9 & 95.4 & 131.6 & 180.8 & 62.4 & 6.0 & 7.0 & 37.6 & 742.5 \\
\hline 2006 & 11.4 & 17.1 & 45.3 & 70.8 & 77.9 & 118.2 & 16.5 & 148.6 & 32.6 & 18.6 & 6.1 & 17.7 & 580.8 \\
\hline 2007 & 12.8 & 30.7 & 24.4 & 10.1 & 103.8 & 77.1 & 54.4 & 118.1 & 84.7 & 93.0 & 25.4 & 20.8 & 655.3 \\
\hline 2008 & 17.3 & 11.2 & 30.3 & 58.4 & 89.0 & 136.8 & 125.2 & 9.0 & 41.0 & 45.4 & 21.1 & 45.9 & 630.6 \\
\hline 2009 & 9.5 & 22.4 & 53.5 & 8.4 & 31.4 & 113.4 & 52.5 & 38.1 & 3.4 & 77.8 & 48.0 & 35.0 & 493.4 \\
\hline 2010 & 39.2 & 30.6 & 17.6 & 52.0 & 87.6 & 172.6 & 121.0 & 49.2 & 67.2 & 31.6 & 30.8 & 40.4 & 739.8 \\
\hline 2011 & 26.8 & 19.9 & 15.3 & 22.6 & 41.4 & 116.8 & 130.4 & 12.8 & 22.8 & 8.8 & 0.2 & 15.2 & 433.0 \\
\hline 2012 & 26.2 & 30.7 & 5.3 & 78.4 & 89.2 & 67.4 & 52.4 & 28.0 & 30.2 & 42.0 & 9.6 & 45.0 & 504.4 \\
\hline 2013 & 19.8 & 10.3 & 57.9 & 53.3 & 79.3 & 86.2 & 37.6 & 44.0 & 57.8 & 67.8 & 5.9 & 3.3 & 523.2 \\
\hline 2014 & 51.6 & 15.5 & 23.1 & 72.0 & 66.2 & 48.4 & 144.4 & 83.8 & 48.4 & 67.4 & 34.2 & 86,6 & 741,5 \\
\hline $\begin{array}{c}\text { Mean } \\
10 \\
\text { years }\end{array}$ & 26.0 & 21.3 & 30.6 & 55.3 & 78.9 & 111.7 & 94.2 & 76.8 & 49.1 & 49.1 & 21.6 & 29.0 & 598.2 \\
\hline $\begin{array}{c}\text { Mean } \\
57 \\
\text { years }\end{array}$ & 21.4 & 18.8 & 23.4 & 45.4 & 68.3 & 84.2 & 75.6 & 55.2 & 40.4 & 32.8 & 28.0 & 26.8 & 520.4 \\
\hline
\end{tabular}

Tab. 3. Chemical soil properties at the beginning experience, 2005

\begin{tabular}{lcccccc}
\hline Variant of work & $\begin{array}{c}\text { Depht soil } \\
\text { sampler }\end{array}$ & $\mathrm{pH}$ & Humus \% & Total nitrogen \% & $\begin{array}{c}\mathrm{P} \\
\mathrm{ppm}\end{array}$ & $\begin{array}{c}\mathrm{K} \\
\mathrm{ppm}\end{array}$ \\
\hline Classical system & $0-20 \mathrm{~cm}$ & 6.30 & 2.94 & 0.162 & 5 & 140 \\
\cline { 2 - 7 } & $20-40 \mathrm{~cm}$ & 7.00 & 2.21 & 0.124 & 0.9 & 126 \\
\hline
\end{tabular}


Tab. 4. Influence of tillage system and fertilization on soil chemical properties SCDA Turda, 2014

\begin{tabular}{lcccccc}
\hline Variant of work & $\begin{array}{c}\text { Depht soil } \\
\text { sampler }\end{array}$ & $\mathrm{pH}$ & $\begin{array}{c}\text { Humus } \\
\%\end{array}$ & $\begin{array}{c}\text { Total nitrogen } \\
\%\end{array}$ & $\begin{array}{c}\mathrm{P} \\
\text { ppm }\end{array}$ & $\begin{array}{c}\mathrm{K} \\
\text { ppm }\end{array}$ \\
\cline { 2 - 7 } & $0-20 \mathrm{~cm}$ & 7.69 & 1.97 & 0.146 & 43 & 250 \\
\hline Classic $\mathrm{N}_{40} \mathrm{P}_{40}$ & $20-40 \mathrm{~cm}$ & 8.07 & 1.42 & 0.090 & 8 & 168 \\
\hline Minumum tillage & $0-20 \mathrm{~cm}$ & 7.81 & 2.39 & 0.275 & 50 & 194 \\
\cline { 2 - 7 } $\mathrm{N}_{40} \mathrm{P}_{40}$ & $20-40 \mathrm{~cm}$ & 8.10 & 1.67 & 0.149 & 10 & 214 \\
\hline Classic $\mathrm{N}_{40} \mathrm{P}_{40+} \mathrm{N}_{30}$ & $0-20 \mathrm{~cm}$ & 7.55 & 2.28 & 0.143 & 23 & 204 \\
\cline { 2 - 6 } & $20-40 \mathrm{~cm}$ & 7.80 & 1.63 & 0.093 & 1 & 168 \\
\hline Minimum tillage & $0-20 \mathrm{~cm}$ & 7.68 & 2.89 & 0.175 & 82 & 258 \\
\cline { 2 - 7 } $\mathrm{N}_{40} \mathrm{P}_{40+} \mathrm{N}_{30}$ & $20-40 \mathrm{~cm}$ & 8.03 & 2.15 & 0.109 & 12 & 214 \\
\hline
\end{tabular}

Tab. 5. Influence of tillage systems on soil resistance

\begin{tabular}{cccc}
\hline Variants & $\begin{array}{c}\text { Value soil penetration } \\
\text { resistance (kPa) }\end{array}$ & $\%$ & Differences \\
\hline Classic & $1059^{\text {wt }}$ & 100.0 & 0.00 \\
\hline Minimum tillage & $1225^{* *}$ & 116 & 167 \\
\hline DL (p 5\%) & & 57 & \\
DL (p 1\%) & & 99 & \\
DL (p 0.1\%) & & 182 & \\
\hline
\end{tabular}

Note:wt - control, ${ }^{* *}$ distinct significance pozitive.

After 10 years of experimentation chemical soil analysis is shown in Tab. 4. The results presents the influence of culture in particular, and depending in soil tillage system.

Although at ARDS Turda, soil reaction is neutral, on land where are located experience, the reaction of soil it is slightly alkaline. In variants with additional fertilization humus content in the middle and the choice of single fertilization humus varies from poor to middle in minimal tillage system compared to the classic system where the variant with one fertilization content is weak and additional fertilization variant in content in humus varies from medium to weak. Total nitrogen, in where soil tillage systems has values that vary from weak at good to classic version where the values are low and very low between limit. In soil phosphorus content: classical limit in very weak - good, minimum between weak very good. Potassium is good-very good framed in limit for each variant of tillage. Influences the physical properties of soil fertility directly which in turn has a strong influence on the water regime, air and soil nutrition. At the same time intensify chemical and biological processes, is easier are the germination of the seeds, entry roots in the soil, and prevents a soil erosion, all these data are provided by the literature. On soils with a high content in phosphorus, strong nodozities develops on roots of legumes, increase their weight and the percentage of nitrogen, increases the nitrogenize activity on nodozities formed. Phosphorus plays an important role in the process of fixing nitrogen biological as the source of energy for converting molecules adenosis-triphosphate (ATP). Potassium influences the symbiotic nitrogen fixation indirectly from legumes, working nitrogenize a vital enzyme for the nitrogen fixation. Soil acidity $(\mathrm{pH})$ affects nitrogen fixation, a $\mathrm{pH}$ less than 6.0 decreases production and 
Tab. 6. Depth influence on the resistance of soil penetration

\begin{tabular}{lccc}
\hline Depth soil penetration $(\mathrm{cm})$ & $\begin{array}{c}\text { Value soil penetration resistance } \\
(\mathrm{kPa})\end{array}$ & $\%$ & Differences \\
\hline $0-5$ & $977^{\text {wt }}$ & 100.0 & 0.00 \\
\hline $5-10$ & $928^{* * *}$ & 95 & -50 \\
\hline $10-15$ & $1102^{* * *}$ & 113 & 313 \\
\hline $15-20$ & $1291^{* * *}$ & 132 & 358 \\
\hline $20-25$ & $1356^{* * *}$ & 137 & 389 \\
\hline $25-30$ & $1367^{* * *}$ & 140 & 421 \\
\hline $30-35$ & $1399^{* * *}$ & 143 & 489 \\
\hline $35-40$ & $1466^{* * *}$ & 150 & 88 \\
\hline DL (p 5\%) & & & 121 \\
DL (p 1\%) & & & 59 \\
DL (p 0.1\%) & & & 38 \\
\hline
\end{tabular}

Note: wt - control, *** very significance pozitive.

Tab. 7. The influence of the interaction between system and depth penetration

\begin{tabular}{|c|c|c|c|c|c|c|}
\hline Variant tillage & Depth $(\mathrm{cm})$ & $\mathrm{T}\left({ }^{\circ} \mathrm{C}\right)$ & $\mathrm{U}(\%)$ & $\mathrm{kPa}$ & $\%$ & Differences \\
\hline Classic & \multirow{2}{*}{$0-5$} & 23.3 & 25.3 & $642^{\mathrm{Wt}}$ & 100 & 0.00 \\
\hline Minimum tillage & & 23.1 & 25.9 & $1064^{* * *}$ & 166 & 422 \\
\hline Classic & \multirow{2}{*}{$5-10$} & 23.1 & 28.8 & $512^{\mathrm{Wt}}$ & 100 & 0.00 \\
\hline Minimum tillage & & 23.4 & 25.7 & $898^{* * *}$ & 176 & 386 \\
\hline Classic & \multirow{2}{*}{$10-15$} & 23.3 & 24.2 & $851^{\mathrm{Wt}}$ & 100 & 0.00 \\
\hline Minimum tillage & & 23.0 & 24.6 & $1101^{* * *}$ & 129 & 250 \\
\hline Classic & \multirow{2}{*}{$15-20$} & 23.2 & 24.4 & $1070^{\mathrm{Wt}}$ & 100 & 0.00 \\
\hline Minimum tillage & & 22.9 & 25.8 & $1244^{* *}$ & 116 & 173 \\
\hline Classic & \multirow{2}{*}{$20-25$} & 23.1 & 27.8 & $1174^{\mathrm{Wt}}$ & 100 & 0.00 \\
\hline Minimum tillage & & 22.8 & 27.3 & $1294^{*}$ & 110 & 120 \\
\hline Classic & \multirow{2}{*}{$25-30$} & 23.2 & 31.5 & $1293^{\mathrm{Wt}}$ & 100 & 0.00 \\
\hline Minimum tillage & & 22.8 & 31.4 & $1335^{-}$ & 103 & 43 \\
\hline Classic & \multirow{2}{*}{$30-35$} & 23.1 & 29.9 & $1447^{\mathrm{Wt}}$ & 100 & 0.00 \\
\hline Minimum tillage & & 23.0 & 29.7 & 1404 & 97 & -43 \\
\hline Classic & \multirow{2}{*}{$35-40$} & 23.1 & 29.5 & $1483^{\mathrm{Wt}}$ & 100 & 0.00 \\
\hline Minimum tillage & & 22.7 & 29.8 & $1460^{-}$ & 98 & -23 \\
\hline DL (p5\%) & & & & & 112 & \\
\hline DL (p 1\%) & & & & & 167 & \\
\hline DL (p $0.1 \%)$ & & & & & 234 & \\
\hline
\end{tabular}

Note: -entrol, $* * *$ very signiffeanee pozitive, $* *$ distinet signiffeanee pozitive.

the number of nodules on root of the legumes. In Tab. 5, we see the influence of tillage system on soil compaction, the values obtained on two systems; compared to the classical (plowing with furrow return) minimum tillage system has distinct significant positive influence, given the value of $1225 \mathrm{kPa}$. Plowing, basic work, main considered the technological operation for incor- 
poration fallow, crop residues, weeds and loosening soil which adds work of extensive seedbed and maintenance by mechanical hoeing crops (hoeing plants) by their action direct and indirect effects influences the soil layer both worked and under arable horizon.

From Tab. 6 and Tab. 7 it can be seen that for all technological options made available until the depth in study included $0-5 \mathrm{~cm}$ between hard penetration resistances does not exceed $1226 \mathrm{kPa}$.

Compared to the classic version in chisel tillage and no amount of $1101 \mathrm{kPa}$, proves that there surface subsidence is a compaction of the surface and that in fact the surface layer of $10 \mathrm{~cm}$ begins to transform into a fertile layer, with incorporate of dry mass of weeds yearly, through fertilizer intake of minerals and soil conservation through the protection offered by the protective vegetal layer and crop plants. Soil resistance in the variant worked with moldboards plow, have values below 1000 $\mathrm{kPa}$, the depth $0-15 \mathrm{~cm}, 20-40 \mathrm{~cm}$ elevated on depth $(1174-1483 \mathrm{kPa})$. Force values are higher in the depth $30 \mathrm{~cm}$, so it is advisable to look for alternate depth stopped hardpan appearance to install in after work (plowing) the same depth.

The values obtained in unconventional tillage systems, below $2000 \mathrm{kPa}$, does not adversely affect the penetration of plant roots grown bet on soil compaction is less dependent on technological variant, more than depth and weather conditions.

Soil moisture the classic on the first $25 \mathrm{~cm}$ depth not exceed $28 \mathrm{~mm}$, increased by 3 percent to $31 \mathrm{~mm} 25-30 \mathrm{~cm}$ depth followed then fall by 2 percent $(29 \mathrm{~mm})$ depth $30-40 \mathrm{~cm}$. In reduced version works (chisel) soil moisture shows similar values 24 to $25 \mathrm{~mm}$, these values increase at 27 $\mathrm{mm}$ to $20 \mathrm{~cm}$ depth. At the depth $25-40 \mathrm{~cm}$ soil moisture is equal to the classic version.

Soil moisture of $31 \mathrm{~mm}$ after $25 \mathrm{~cm}$ depth, indicate a greater reserve of water in the soil. A humidity 24-25 mm large enough to work with heavy machinery as produce compaction surface.

Temperature was in the normal limits for the period or the period when measurements were made between, grouped around $22-23^{\circ} \mathrm{C}$ on whatever depth, at all technologies. The values at 25$40 \mathrm{~cm}$ in classic and chisel variants were relatively close to $22-23^{\circ} \mathrm{C}$. This may indicate a correlation between system-temperature-humidity.

\section{CONCLUSIONS}

Chemical fertilizers should be applied as a complement to reserve accessible and mobile existing soil nutrients, and soil agrochemical study is necessary.

In minimum tillage systems acquisition and preservation of water is easier to achieve compared to the classic where the large number of works, dry years, water is lost easily.

The largest increase on $\mathrm{pH}$, to registered if soybean crop fertilization +1 in minimum system version, passes from weak acid to slightly alkaline. Moreover it can be seen an increase more or less significant $\mathrm{pH}$ in all variants, which can be explained by physiological reaction alkaline fertilizer used.

Among the most prominent macro increase the nitrogen content (70\%) as expected, soybean crop registered in minimum tillage + fertilization variant, which is explained by the contribution on this element soybean crop through nitrogen fixing bacteria. All if in soybean crop fertilization variant minimum tillage +2 to registered best phosphorus content (up to $77 \mathrm{ppm}$ ) content that is from very small to very good supply.

The force (soil resistance to penetration) are higher in $30 \mathrm{~cm}$ depth, with traditional plowing, so it is advisable to look for alternate depth stopped to install hardpan appearance after plowing the same depth.

Acknowledgments: This paper was published under the frame of European Social Fund, Human Resources Development Operational Programme 20072013, project no. POSDRU/159/1.5/S/132765.

\section{REFERENCES}

1. Berca M (2006). Planificarea de mediu şi gestiunea resurselor naturale, Ed. Ceres, București.

2. Carter MR (1994). Conservation Tillage in Temperatur Agrosystems. Lewis Publishers An Arbor London;

3. Rusu T, Bogdan I, Pop AI (2012). Îndrumător de lucrări practice la Agrotehnică. Ed. Grinta, Cluj-Napoca.

4. Stefanic G (1976). Modificări chimice și biologice în sol sub actiunea arăturii la diferite adâncimi şi a fertilizării, Analele Inst. Agro. Craiova.

5. Stefanic G (1997). Influenta modului de afânare si alternãrii lucrãrilor de bazã asupra stãrii vitale a solului, "Alternative de lucrare a solului", Cluj-Napoca, I: 123-129. 